\title{
Increased detection of Mycoplasma pneumoniae infection in children, Lyon, France, 2010 to 2011
}

D Eibach (daniel.eibach@chu-lyon.fr) ${ }^{1,2,3,4}$, J S Casalegno ${ }^{1,2,4}$, V Escuret ${ }^{1,2}$, G Billaud $^{1}$, Y Mekki ${ }^{1}$, E Frobert ${ }^{1,2}$, M BouscambertDuchamp $^{1}$, B Lina ${ }^{1,2}$, F Morfin ${ }^{1,2}$

1. Laboratory of Virology, Centre de Biologie et Pathologie Est, Hospices Civils de Lyon, Lyon, France

2. Virologie et Pathologie Humaine (VirPath), EMR 4610, Université Lyon 1 - Université de Lyon, Hospices Civils de Lyon, Lyon, France

3. European Public Health Microbiology Training Programme (EUPHEM), European Centre for Disease Prevention and Control (ECDC), Stockholm, Sweden

4. Both authors contributed equally to this work and share first authorship

Citation style for this article:

Eibach D, Casalegno JS, Escuret V, Billaud G, Mekki Y, Frobert E, Bouscambert-Duchamp M, Lina B, Morfin F. Increased detection of Mycoplasma pneumoniae infection in children, Lyon, France, 2010 to 2011

Euro Surveill. 2012;17(8):pii=20094. Available online: http://www.eurosurveillance.org/ViewArticle.aspx?Articleld=20094

Article published on 23 February 2012

Recent reports from several northern European countries indicate an increase in detection of Mycoplasma pneumoniae infection in the past two years, notably in children aged 5-15 years. Analysis of our laboratory database showed a similar pattern, with a higher proportion of respiratory samples positive for $M$. pneumoniae by real-time PCR in paediatric patients aged 5-15 years. Our data indicate that in 2010 and 2011, France experienced the first epidemic peak of $M$. pneumoniae infection since 2005 .

An increased number of cases of Mycoplasma pneumoniae infections have recently been reported in northern Europe, including Denmark, Norway, Finland, Sweden, the Netherlands and England [1-6]. Till now, there were no available surveillance data on the current situation in France or any other country in southern Europe. The Lyon Laboratory of Virology serves the university hospitals in the metropolitan area of Lyon, with an estimated catchment area of 2.1 million people. We investigated our laboratory database in order to determine if a similar increase in the number of $M$. pneumoniae infections could be observed during the past nine years. Our study shows a striking similar pattern as that seen in Norway [3] and also confirms a current outbreak of $M$. pneumoniae infection in children.

M. pneumoniae is known to cause respiratory tract infections. It is contracted through droplets and affects primarily children aged between 5 and 15 years, with an estimated $20 \%$ of asymptomatic infections occurring in this age group $[7,8]$. It is the most common pathogen detected in paediatric community-acquired pneumonia [7].

\section{Analysis of laboratory data}

Laboratory diagnosis for M. pneumoniae has been historically based on a fourfold rise of antibody titres in a serological assay, with more sensitive methods, such as PCR, the gold standard, being used in Mycoplasma diagnostics in some laboratories during recent years [9].

As infections with $M$. pneumoniae are not notifiable in France, we analysed all $M$. pneumoniae-positive reports in the Lyon Laboratory of Virology during the study period of January 2003 to December 2011. Until September 2011, we used an in-house real-time PCR based on Hardegger et al. [10], which was then replaced by the Chlamydia pneumoniae/M. pneumoniae Respiratory Multi Well System r-gene, a real-time PCR kit (bioMérieux-Argène, France).

During the study period, the $M$. pneumoniae PCR was performed on a total of 11,302 respiratory samples, with a mean of 1,280 respiratory samples per year. The samples had been mainly taken from paediatric patients, with $53.4 \%$ of the patients aged under 16 years. These paediatric samples came from the following hospital departments: paediatric emergency department (29.3\%), intensive care units (14.5\%) and various inpatient departments, mainly pneumology and haematology departments (56.2\%). The samples from adults (aged over 15 years) were received from various inpatient departments $(65.8 \%)$ and intensive care units $(34.2 \%)$.

We detected a $\mathbf{1 5 . 1 \%}$ increase in the number of respiratory samples sent to the laboratory for M. pneumoniae PCR from $2009(n=819)$ to $2010(n=943)$ and another $30.3 \%$ increase to the year $2011(n=1,229)$. The main reason for this was the increased number of samples sent for testing from the paediatric emergency department, where the number of respiratory samples rose by $53.9 \%$ from the number in $2009(n=191)$ to 2010 $(n=294)$; comparison with 2009 alone showed an increase of $185.3 \%$ in $2011(n=545)$. During the same time period (2009-2011), the number of samples sent 
for the detection of $M$. pneumoniae from paediatric intensive care units and the adult hospital departments remained at the same level.

Coincident with the increase in the number of respiratory samples received in 2010 and 2011, we observed an increase in the number of laboratory-confirmed cases of $M$. pneumoniae infection when compared with the number in 2009 (Figure). Considering the overall pattern in the past nine years, two main epidemic periods for the detection of $M$. pneumoniae can be identified. The first occurred in 2005 , followed by a slow decrease in numbers until 2009. In 2010, the number of $M$. pneumoniae started to rise again - resulting in a second epidemic period - and continued to rise until the end of the study period, December 2011 (Figure). To date, the epidemic seems to be ongoing.

When looking at the ages of patients with M. pneumoniae infection, we observed a general rise in the number of infections in all age groups in 2010 and 2011. The largest rise and the highest percentage of

\section{FIGURE}

Annual number of laboratory-confirmed cases of Mycoplasma pneumoniae infection, detected by real-time PCR in the Laboratory of Virology, Lyon, France, 2003$2011(\mathrm{n}=423)$

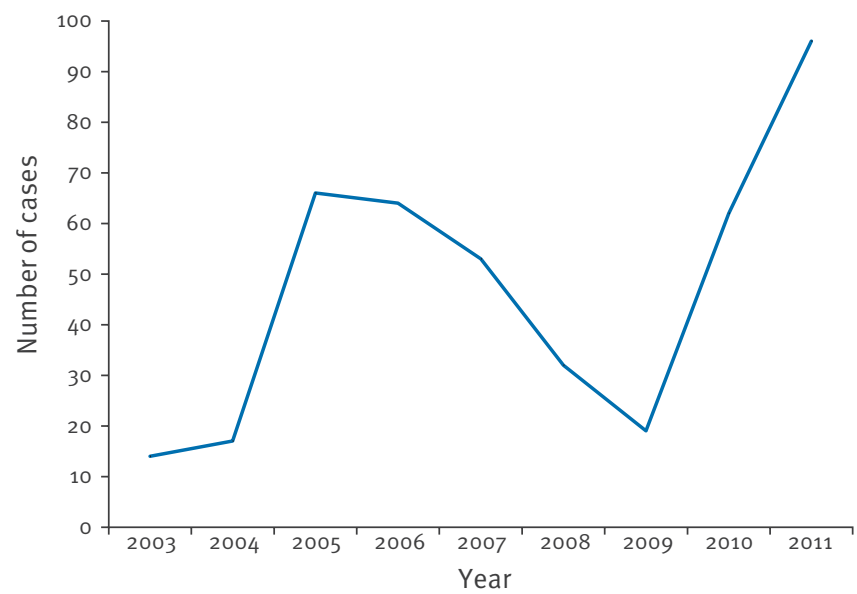

positive samples were found in patients aged 5-15 years, with $14.8 \%$ of all samples being positive for M. pneumoniae in both years; in 2009, the percentage of positive samples was only $7.1 \%$. Among patients aged $0-4$ years, the percentage increased from $0.6 \%$ in 2009 to $4.0 \%$ in 2010 and $5.5 \%$ in 2011. In patients aged over 15 years, the percentage of $M$. pneumoniaepositive samples was lower, but still rose from $0.9 \%$ in 2009 to $2.8 \%$ in 2011 . In the nine years, no shift in the age distribution of patients with $M$. pneumoniae infection was observed (Table).

\section{Discussion}

The proportion of $M$. pneumoniae-positive tests in our study correlates well with findings of the PCR-based study in Denmark, where approximately $3 \%$ of PCRs for M. pneumoniae in 2007 were positive, increasing to $15 \%$ during 2010 [11]. Surveillance data from Finland, based mainly on serology results, gave similar proportions, with $8-17 \%$ of tests positive for $M$. pneumoniae in 2010 and 2011 [2]. The detection rate of M. pneumoniae by PCR was highest in Sweden, at $23 \%$ in both 2006 and 2011 [6], which is as high as the percentage we observed during the peak in 2005 in the age group 5-15 years. In our study, the substantial increase in the number of samples originating from the paediatric emergency department clearly underlines the importance of $M$. pneumoniae as a community-acquired pathogen, primarily spreading in childcare facilities or schools. There was no increase in the number of samples sent for $M$. pneumoniae detection from inpatient departments. A nosocomial spread of the infection is therefore not expected.

The proportion of $M$. pneumoniae-positive PCRs among children aged 5-15 years has risen from $7.1 \%$ in 2009 to $14.8 \%$ in both 2010 and 2011 . Such a high percentage has not been seen since the 2005-2007 period. A similar increase was seen, but to a lesser extent, in children aged $0-4$ years (0.6\% in 2009 to $4.0 \%$ and $5.5 \%$ in 2010 and 2011, respectively) and in the adult population (0.9 in 2009 to $3.3 \%$ and $2.8 \%$ in 2010 and 2011, respectively). Nevertheless, children of school age are the group mainly affected by $M$. pneumoniae infection.

\section{TABLE}

Annual percentage of Mycoplasma pneumoniae-positive samples by patient age group, detected by real-time PCR in the Laboratory of Virology, Lyon, France, 2003-2011

\begin{tabular}{|c|c|c|c|c|c|c|c|c|c|}
\hline \multirow{2}{*}{$\begin{array}{l}\text { Patient age } \\
\text { group in years }\end{array}$} & \multicolumn{9}{|c|}{ Percentage of positive samples ( $95 \%$ confidence interval) } \\
\hline & 2003 & 2004 & 2005 & 2006 & 2007 & 2008 & 2009 & 2010 & 2011 \\
\hline $0-4$ & $\begin{array}{c}1.2 \\
(0.0-1.5)\end{array}$ & $\begin{array}{c}2.0 \\
(0.5-5.0)\end{array}$ & $\begin{array}{c}6.4 \\
(3.9-9.8)\end{array}$ & $\begin{array}{c}3.5 \\
(2.1-5.6)\end{array}$ & $\begin{array}{c}3.2 \\
(1.9-5.2)\end{array}$ & $\begin{array}{c}3.8 \\
(2.2-6.4)\end{array}$ & $\begin{array}{c}0.6 \\
(0.1-2.2)\end{array}$ & $\begin{array}{c}4.0 \\
(2.4-6.4)\end{array}$ & $\begin{array}{c}5 \cdot 5 \\
(3 \cdot 9-7.5) \\
\end{array}$ \\
\hline $5-15$ & $\begin{array}{c}8.9 \\
(4 \cdot 7-15.0)\end{array}$ & $\begin{array}{c}7.3 \\
(3.2-13.8)\end{array}$ & $\begin{array}{c}25.0 \\
(18.9-32.0)\end{array}$ & $\begin{array}{c}18.1 \\
(13 \cdot 5-23.7)\end{array}$ & $\begin{array}{c}13.0 \\
(8.9-18.0)\end{array}$ & $\begin{array}{c}7 \cdot 7 \\
(4.6-12.1) \\
\end{array}$ & $\begin{array}{c}7.1 \\
(4.1-11.3) \\
\end{array}$ & $\begin{array}{c}14.8 \\
(10.8-19.5)\end{array}$ & $\begin{array}{c}14.8 \\
(11.4-18.9)\end{array}$ \\
\hline$>15$ & $\begin{array}{c}0.2 \\
(0.0-0.5)\end{array}$ & $\begin{array}{c}0.5 \\
(0.2-1.1) \\
\end{array}$ & $\begin{array}{c}0.6 \\
(0.2-1.6) \\
\end{array}$ & $\begin{array}{c}1.3 \\
(0.7-2.5) \\
\end{array}$ & $\begin{array}{c}1.1 \\
\left(0.5^{-2.3}\right)\end{array}$ & $\begin{array}{c}0.4 \\
(0.1-1.4)\end{array}$ & $\begin{array}{c}0.9 \\
(0.1-3.0)\end{array}$ & $\begin{array}{c}3.3 \\
(1.4-6.5)\end{array}$ & $\begin{array}{c}2.8 \\
(0.9-6.3)\end{array}$ \\
\hline Total & $\begin{array}{c}1.2 \\
(0.7-2.0)\end{array}$ & $\begin{array}{c}1.2 \\
(0.7-2.0)\end{array}$ & $\begin{array}{c}5 \cdot 5 \\
(4 \cdot 3-6.9)\end{array}$ & $\begin{array}{c}4 \cdot 7 \\
(3.7-6.0)\end{array}$ & $\begin{array}{c}3.7 \\
(2.9-4.9)\end{array}$ & $\begin{array}{c}2.9 \\
(2.0-4.0)\end{array}$ & $\begin{array}{c}2.4 \\
(1.5-3.8) \\
\end{array}$ & $\begin{array}{c}7.0 \\
(5.5-8.9)\end{array}$ & $\begin{array}{c}7.9 \\
(6.5-9.6)\end{array}$ \\
\hline
\end{tabular}


The two epidemic periods, 2005-2007 and since 2010, correspond to the distribution of cases of $M$. pneumoniae infection in other European countries, such as Sweden, Finland and Norway [2,3,6]. Epidemic periods, occurring after a four-year interval and lasting for approximately 18 months, have also been reported from England [12].

A general surveillance system for $M$. pneumoniae as in other European countries, including typing of a single or different strains in outbreak situations [13,5], would simplify the detection of the strains responsible for the reoccurring epidemics in France.

Data on macrolide resistance of the circulating $M$. pneumoniae isolates in France are currently not available, but this issue needs to be assessed in the near future.

\section{References}

1. Lenglet A, Herrador Z, Magiorakos AP, Leitmeyer K, Coulombier D, European Working Group on Mycoplasma pneumoniae surveillance. Surveillance status and recent data for Mycoplasma pneumoniae infections in the European Union and European Economic Area, January 2012. Euro Surveill. 2012;17(5):pii=20075. Available from: http://www. eurosurveillance.org/ViewArticle.aspx?Articleld=20075

2. Polkowska A, Harjunpää A, Toikkanen S, Lappalainen $M$, Vuento R, Vuorinen T, et al. Increased incidence of Mycoplasma pneumoniae infection in Finland, 2010-2011. Euro Surveill. 2012;17(5):pii=20072. Available from: http://www. eurosurveillance.org/ViewArticle.aspx?Articleld $=20072$

3. Blystad H, Ånestad G, Vestrheim DF, Madsen S, RønningK. Increased incidence of Mycoplasma pneumoniae infection in Norway 2011. Euro Surveill. 2012;17(5):pii=20074. Available from: http://www.eurosurveillance.org/ViewArticle. aspx?Articleld $=20074$

4. Uldum SA, Bangsborg JM, Gahrn-Hansen B, Ljung R, Mølvadgaard M, Føns Petersen R, et al. Epidemic of Mycoplasma pneumoniae infection in Denmark, 2010 and 2011 Euro Surveill. 2012;17(5):pii=20073. Available from: http:// www.eurosurveillance.org/ViewArticle.aspx?Articleld $=20073$

5. Chalker VJ, Stocki T, Litt D, Bermingham A, Watson Fleming DM, Harrison TG Increased detection of Mycoplasma pneumoniae infection in children in England and Wales, October 2011 to January 2012. Euro Surveill. 2012;17(6):pii=20081. Available from: http://www. eurosurveillance.org/ViewArticle.aspx?Articleld =20081

6. Linde A, Ternhag A, Törner A, Claesson BE. Antibiotic prescriptions and laboratory-confirmed cases of Mycoplasma pneumoniae during the epidemic in Sweden in 2011. Euro Surveill. 2012;17(6):pii=20082. Available from: http://www. eurosurveillance.org/ViewArticle.aspx?Articleld =20082

7. Atkinson TP, Balish MF, Waites KB. Epidemiology, clinical manifestations, pathogenesis and laboratory detection of Mycoplasma pneumoniae infections. FEMS Microbiol Rev. 2008;32(6):956-73.

8. Waites KB, Talkington DF. Mycoplasma pneumoniae and its role as a human pathogen. Clin Microbiol Rev. 2004;17(4):697-728.

9. Beersma MF, Dirven K, van Dam AP, Templeton KE, Claas EC, Goossens H. Evaluation of 12 commercial tests and the complement fixation test for Mycoplasma pneumoniae-specific immunoglobulin G (IgG) and IgM antibodies, with PCR used as the "gold standard". J Clin Microbiol. 2005;43(5):2277-85.

10. Hardegger D, Nadal D, Bossart W, Altwegg M, Dutly F. Rapid detection of Mycoplasma pneumoniae in clinical samples by real-time PCR. J Microbiol Methods. 2000;41(1):45-51.

11. Rasmussen JN, Voldstedlund M, Andersen RL, EllermannEriksen S, Jensen TG, Johansen HK, et al. Increased incidence of Mycoplasma pneumoniae infections detected by laboratory-based surveillance in Denmark in 2010. Euro Surveill. 2010;15(45):pii=19708. Available from: http://www. eurosurveillance.org/ViewArticle.aspx?Articleld=19708

12. Nguipdop Djomo P. Contribution to understanding the dynamics of Mycoplasma pneumoniae infections in England and Wales [dissertation]. London: London School of Hygiene and Tropical Medicine, University of London; 2009.
13. Pereyre S, Renaudin H, Charron A, Bébéar C. Clonal spread of Mycoplasma pneumoniae in primary school, Bordeaux, France. Emerg Infect Dis. 2012;18(2):343-5. 